14. Cetinkaya F. The relation between recurrent acute subglottic laryngitis and asthma in children / F. Cetinkaya, S. Turgut // Int. J. Pediatr. Otorhinolaryngol. - 2001. - Vol. 57, N 1 - P. 41-43.

15. Nicolai T. Risk of asthma in children with a history of croup / T. Nicolai, E.V. Mutius // Acta Paediatr. - 1996. - Vol. 85, N 11. P.1295-1299.

16. Croup and recurrent croup: their association with asthma and allergy. An epidemiological study on 5-8-year-old children / [H.P. Van Bever, M.H. Wieringa, J.J. Weyler et al.] // Eur. J. Pediatr. - 1999. Vol. 158, N 3. - P. 253-257.

17. Distinct roles for IL-13 and IL-4 via IL-13 receptor alpha1 and the type II IL-4 receptor in asthma pathogenesis / [A. Munitz, E.B. Brandt, M. Mingler et al.] // Proc. Natl. Acad. Sci. USA. - 2008. - Vol. 105. - P. 7240-7245.

\section{A ROLE OF ALLERGY IN GENESIS OF LARYNGOTRACHEITIS AND RECURRENT LARYNGOTRACHEITIS IN CHILDREN}

\author{
L.M. Stanislavchuk
}

SUMMARY. To determine the incidences of asthma in the family history and the serum IL-4 and total IgE levels in children with laryngotracheitis (LT), recurrent laryngotracheitis (RLT) and asthma. Number of incidences for asthma in relatives of children with asthma and RLT was higher compared to the number of incidences in relatives of children with LT. The serum IL-4 and total IgE levels in children with $L T, R L T$ and asthma were significantly higher than those in control group with the highest values in children with asthma. The IL-4 and total IgE levels in children with RLT exceeded those in children with $L T$. The analysis results indicate a more significant role of allergy in genesis of RLT than in genesis of $L T$.

Key words: laryngotracheitis, recurrent laryngotracheitis, asthma, total IgE, interleukin-4.

Отримано 21.12.2015 р.

\title{
ЧИ ВІДПОВІДАЕ КЛІНІЧНА РЕМІСІЯ РЕЦИДИВНОГО ОБСТРУКТИВНОГО БРОНХІТУ ВІДСУТНОСТІ ІМУНОЛОГІЧНИХ ЗМІН У РЕСПІРАТОРНОМУ ТРАКТІ ДІТЕЙ?
}

\author{
Інститут епідеміології та інфекційних хвороб ім. Л.В. Громашевського НАМН України
}

Проведено дослідження ролі вмісту інтерлейкінів (ІЛ)-4, -6, -8, -10 в слині у пацієнтів з рецидивним обструктивним бронхітом (РОБ) під час ремісії і здорових дітей. Встановлено, що за відсутності клінічних проявів РОБ у цих дітей тривають імунопатологичні процеси. Показано, що за даними анамнезу, особливостями клінічних проявів і результатами визначення ІЛ-4, -6, -8, -10 в слині в групі дітей з РОБ можна розмежувати дві підгрупи: пацієнтів з інфекційно-асоційованим РОБ і захворюванням, що має алергічний генез. Для дітей 3 алергічним генезом хвороби характерним є обтяжений алергологічний анамнез у сім'ї, атопічний дерматит на першому році життя, розвиток загострення після контакту з тваринами або переважно під час цвітіння рослин, відсутність вираженої температурної реакції під час розвитку бронхообструктивного синдрому в поєднанні з істотно підвищеним вмістом ІЛ-4 в слині. Для пацієнтів з інфекційно-асоційованим РОБ характерна відсутність алергічних захворювань у батьків та інших членів сім'ї, сезонність загострень з листопада по 
квітень, розвиток загострень бронхообструктивного синдрому в поєднанні з феебрильною температурою тіла і катаральними явищами, а також підвищенням вмісту в слині рівнів ІЛ-6, -8 і зниженням вмісту ІЛ-10. Зазначені особливості можуть враховуватися при оцінці прогнозу перебігу захворювання та визначенні підходів до дифреренційованої терапії.

Ключові слова: діти, респіраторні інфекції, рецидивний обструктивний бронхіт.

Хоча діагностика рецидивного обструктивного бронхіту (РОБ) у дітей зазвичай не становить серйозної проблеми для лікарів-педіатрів, істотні складнощі можуть бути пов'язані із веденням пацієнтів. Зазвичай хворі, що мають повторні напади бронхообструктивного синдрому, спостерігаються і ведуться як пацієнти із бронхіальною астмою. В той же час не викликає сумнівів, що повторні епізоди необструктивного бронхіту спричинені інфекційними чинниками, зокрема насамперед респіраторними вірусами [1, 2] . Однак на сьогодні з'являються публікації, які вказують на важливе значення інорекційних чинників, зокрема їхньої персистенції в стінці бронхів, і розвитку спричиненого ними запалення [3].

3 усіх точок зору, які стосуються надання допомоги пацієнтам, найбільш доцільно запобігати розвитку нападів бронхообструкції, ніж проводити невідкладну терапію [2].

У дітей старше 6 років об'єктивним методом дослідження, що дозволяє оцінити стан прохідності респіраторного тракту, $є$ спірометрія, під час проведення якої можливо визначити динамічні показники системи зовнішнього дихання і, таким чином, оцінити прохідність дихальних шляхів, відповідно, провести корекцію лікування в дітей зі зниженими показниками. В дітей раннього віку технічно неможливо проведення цього дослідження, тому що воно передбачає свідоме ставлення до цієї маніпуляції. Однак, спірометрія не дозволяє оцінити домінуючі механізми запалення стінки бронхів. Тому існує необхідність удосконалення підходів до обстеження дітей з РОБ, спрямоване на визначення групи ризику розвитку рецидиву. Такі діти потенційно можуть потребувати більш активної терапії.

На сьогодні встановлено, що в основі РОБ лежать запальні зміни у стінці бронхів. Важливе значення у патогенезі уражень респіраторного тракту має дисоункція з боку імунної системи, зокрема порушення фрормування окремих субпопуляцій Т-хелперів 1- та 2-го типу, які скеровують запалення в різні напрямки [4]. Оцінити напрямок і інтенсивність зсувів у системі Т-хелперів можна шляхом визначення медіаторів, що продукуються цими клітинами [5].
Нашу увагу привернули ІЛ-4, -6, -8, -10. Це пов'язано 3 тим, що ІЛ-4 є ключовим стимулом, який індукує дифреренціювання Т-лімфроцитів у напрямку Т-хелперів 2 типу, а імунна відповідь спрямовується в бік продукції $\operatorname{lgE}$ та IgG4, що відповідає алергічній гілці патогенезу РОБ [6]. Хоча ІЛ-6 та ІЛ-8 є прозапальними цитокінами, підвищення яких відбувається загалом при запальних реакціях, між ними існують суттєві відмінності. Так, ІЛ-6 сприяє дисреренціюванню імунокомпетентних клітин специфічного імунітету, тоді як ІЛ-8 $€$ хемокіном, що сприяє залученню насамперед фрагоцитуючих клітин [5]. Продукція ІЛ-10 відповідає активації клітин, які вгамовують запалення, тим самим перешкоджаючи надмірній активації імунної системи. Оцінка вмісту цитокінів може проводитися в різних біологічних середовищах - крові, слині, сльозній рідині, тощо [7]. Більшість робіт побудована на визначенні рівнів тих чи інших цитокінів у крові $[8,9]$. Однак при цьому не враховується, що більшість патологічних процесів в організмі людини відбувається на місцевому рівні. В цьому випадку системність змін скоріше є винятком, аніж нормою. Також на рівні тих чи інших біологічно-активних речовин у сироватці крові впливають не лише інтенсивність їхнього утворення, але й швидкість долання гістогематичних бар'єрів, що відділяють локус ураження від крові, об'єм розподілу в організмі, швидкість елімінації. Тому підхід до оцінки інтенсивності змін в бронхолегеневій системі за рівнями цитокінів у крові не можна вважати оптимальним.

На сьогодні існують роботи, в яких показано, що визначення рівнів цитокінів у слині $€$ неінвазивною інформативною методикою оцінки процесів, що відбуваються в імунній системі [6]. Особливе значення визначення цитокінів у слині має при патологічних процесах, які локалізовані в стінках органів і систем організму, вкритих слизовими оболонками (шлунково-кишкового тракту, дихальної системи тощо) $[10,11]$. Це пов'язано з явищем спільності фрункціонування імунної системи місцевого імунітету, яке обумовлює, що імунна відповідь, яка розпочалася в одному локусі слизових оболонок, завдяки міграції імунокомпетентних клітин поширюється на інші слизові, розташовані навіть віддалено від первинного вогнища запалення $[12,13]$.

\section{Пацієнти і методи}

Усього було обстежено 69 дітей віком від 1 до 14 років, дівчаток було 32 (46,37\%), хлопчиків 37 (53,63\%). Вивчали родинний анамнез, анамнез хвороби, також усім дітям проводили загально-клінічне обстеження. На підставі даних анамнезу дітей, що мали РОБ, було сорормовано дві групи: діти з ймовірно інфекційно-асоційованим рецидивним обструктивним бронхітом та діти з ймовірно алергічним генезом РОБ. До першої групи дітей з ймовірно 
інфрекційно-асоційованим генезом захворювання увійшли 22 пацієнти. На зв'язок РОБ з інфекцією вказували відсутність алергічних захворювань у батьків та інших членів родини, сезонність загострень з листопада по квітень, розвиток загострень бронхообструктивного синдрому супроводжувало підвищення температури тіла до фребрильних значень, в поєднанні з іншими катаральними проявами (риніту, фрарингіту).

Група дітей з ймовірно алергічним механізмом розвитку РОБ нараховувала 24 пацієнти. Про алергічну природу захворювання свідчили обтяжений алергологічний анамнез в родині, атопічний дерматит на першому році життя, розвиток загострення після контакту з тваринами або переважно під час цвітіння рослин, відсутність вираженої температурної реакції під час бронхообструктивного синдрому.

Також для порівняння було залучено 22 практично здорові дитини, з необтяженим за алергічними, хронічними бронхолегеневими захворюваннями анамнезом. Розподіл дітей у досліджуваних групах за віком та статтю був відповідним.

Дослідження у дітей з РОБ проводилося під час ремісії, коли впродовж щонайменше останніх двох тижнів діти не мали жодних проявів захворювання, під час об'єктивного дослідження (в тому числі аускультації легень) не було виявлено жодних відхилень.

Для оцінки напрямку та інтенсивності змін з боку імунної системи, локалізованої в респіраторному тракті, проводилося визначення вмісту ІЛ-4, -6, -8, -10 у слині. У дітей перших двох років життя матеріал забирався шляхом відсмоктування слини стерильною трубочкою, у дітей більш старшого віку матеріал отримували шляхом безпосереднього забору.

Визначення вмісту цитокінів проводили імуноферментним методом на багатоканальному фотометрі «STAT FAX» (США) у відповідності до інструкцій виробників. Реєстрація результатів кольорової ІФА-реакції відбувається за допомогою фотометра вертикального сканування (ІФА-рідера). Інтенсивність реакції прямо пропорційна кількості специсрічних антитіл в біопробі [2]. Концентрацію ІЛ-4, -6, -8, -10 визначали за допомогою тест-систем ІФА для кількісного визначення виробництва «Вектор-Бест» (Росія, м. Новосибірськ).

\section{Результати досліджень та їх обговорення}

Середній вміст ІЛ-4 у слині дітей з рецидивним обструктивним бронхітом під час ремісії та дітей контрольної групи наведений на мал. 1.

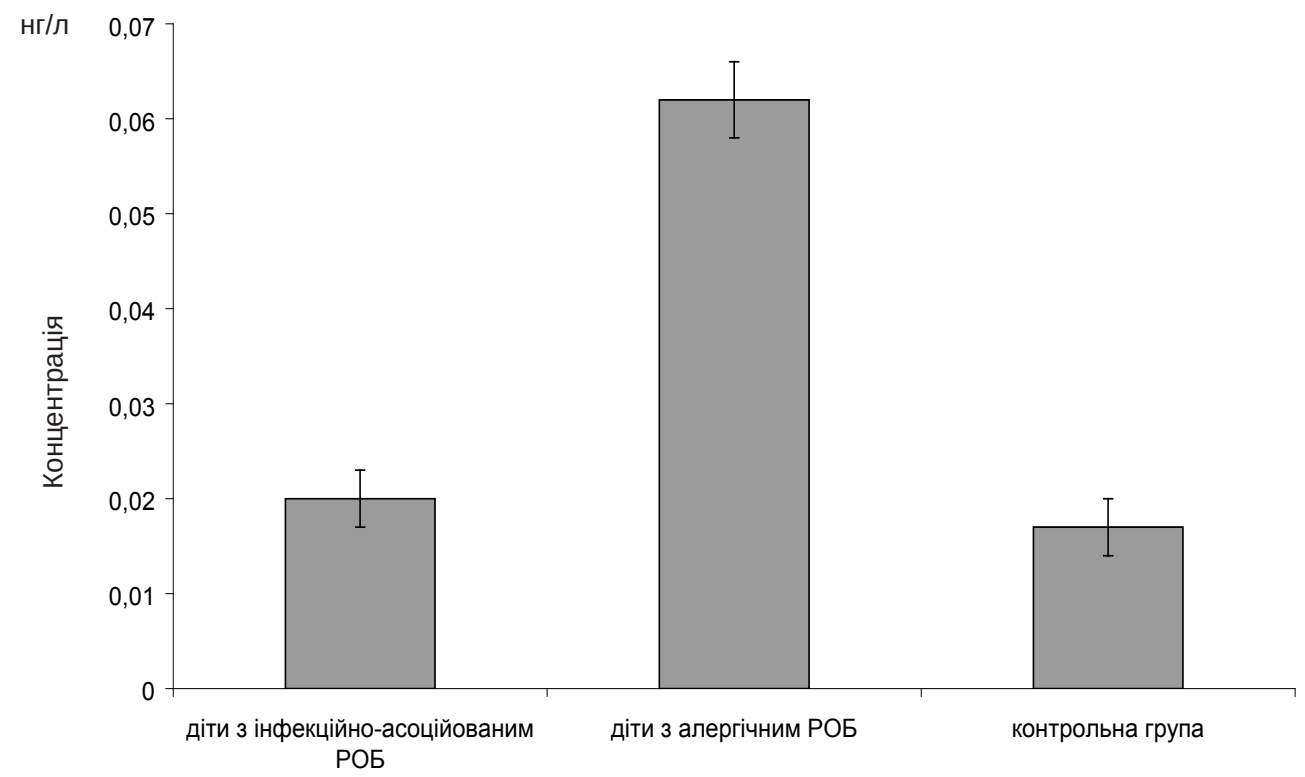

Мал. 1. Середній вміст ІЛ-4 у слині дітей з рецидивним обструктивним бронхітом.

Як випливає з цього малюнку, вміст ІЛ-4 в слині дітей з ймовірно алергічним генезом бронхообструктивного синдрому достовірно ( $p<0,001)$ перевищував рівні, визначені в слині дітей з ймовірно іноееційноасоційованим РОБ та здорових дітей контрольної групи. Це вказує на активацію Т-хелперів 2 типу і, відповідно, розвиток патологічного процесу за алергічною моделлю патогенезу. В той же час відсутність відхилення рівня ІЛ-4 у дітей з ймовірно інфекційно-асоційованим РОБ порівняно із здоровими дітьми вказує на інший патогенетичний механізм розвитку РОБ.

Середній вміст ІЛ-6 у слині дітей 3 рецидивним обструктивним бронхітом та дітей контрольної групи представлений на малюнку 2. 


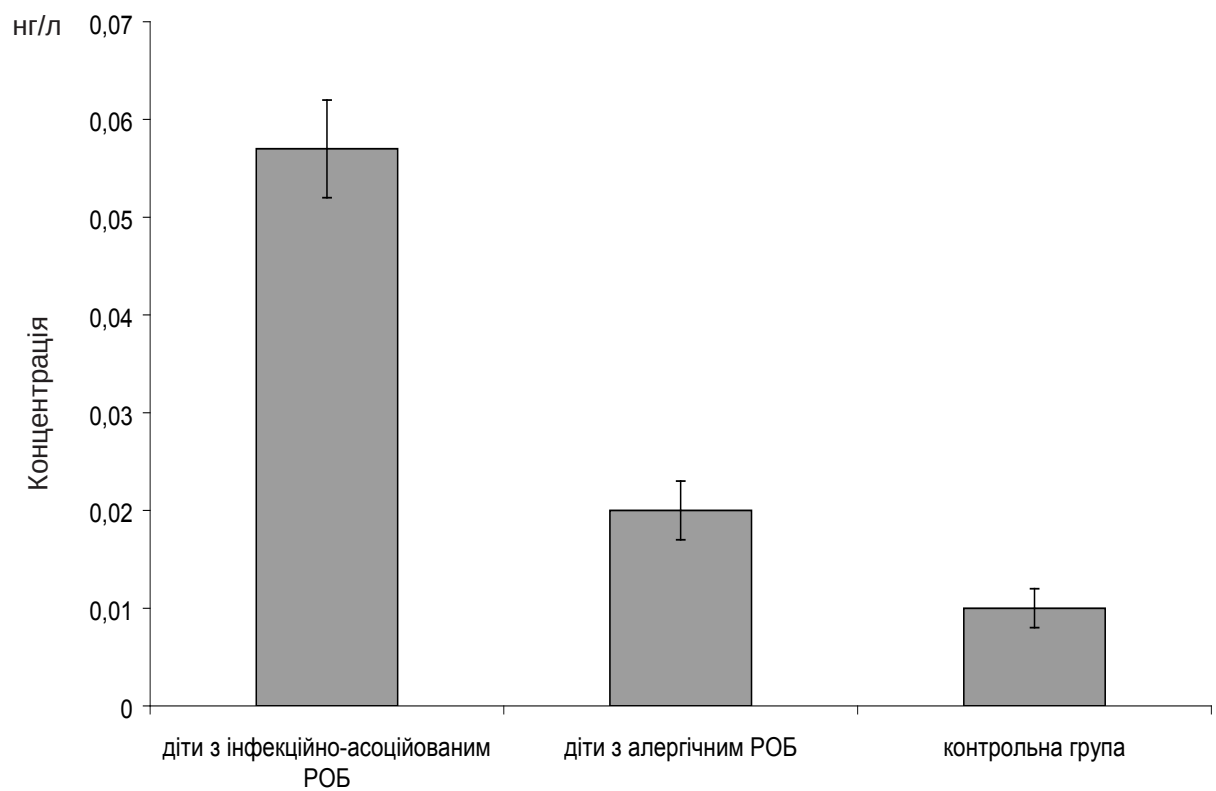

Мал. 2. Середній вміст ІЛ-6 у слині дітей з рецидивним обструктивним бронхітом.

Як можна побачити, найвищій рівень ІЛ-6 спостерігався у хворих, в яких РОБ мав ймовірно інфрекційний генез. Він значно перевищував відповідні показники, визначені в дітей з ймовірно алергічним генезом бронхообструктивного синдрому та здорових дітей контрольної групи. Це вказує на активацію неспецисрічних захисних фракторів у респіраторному тракті цих хворих. Хоча у дітей з алергічним генезом рівні ІЛ-6 перевищували відповідні показники, визначені у здорових дітей, однак ці відмінності виявилися недостовірними. Можна припустити, що у деяких дітей з ймовірно алергічним генезом РОБ напередодні мала місце вірусна інфекція респіраторного тракту, що вплинуло на середнє значення цього показника.

Рівні ІЛ-8 у слині обстежених дітей виявилися найвищими серед інших прозапальних цитокінів (мал. 3). Як і у випадку ІЛ-6, рівні ІЛ-8 у пацієнтів з ймовірно інфекційноасоційованим РОБ достовірно перевищували відповідні показники в пацієнтів з ймовірно алергічним генезом РОБ та здорових дітей. Це вказує на розвиток хронічного неспецифрічного запального процесу у респіраторному тракті цих пацієнтів.

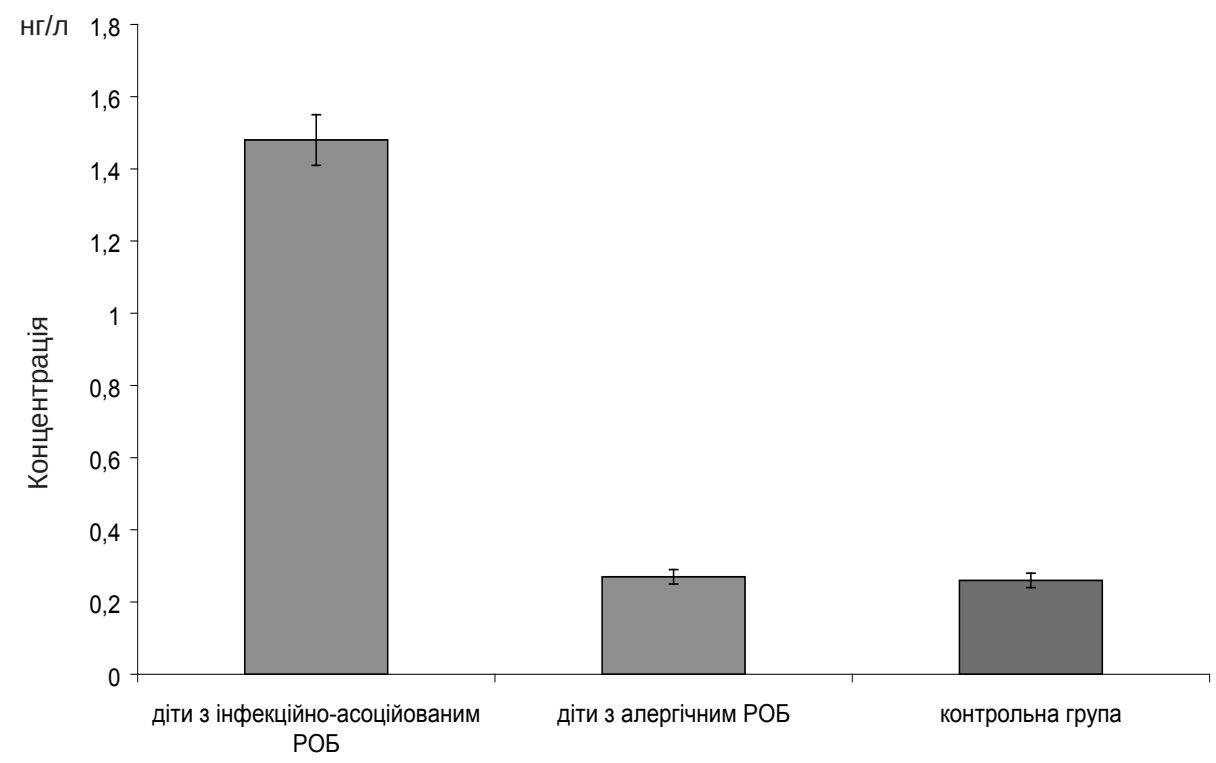

Мал. 3. Середній вміст ІЛ-8 у слині дітей з рецидивним обструктивним бронхітом. 
В нормальних умовах при фрізіологічному перебігу запального процесу індукція прозапальних змін циклічно змінюється активацією протизапальних механізмів, од- ним 3 яких є ІЛ-10, середній вміст якого у слині дітей 3 рецидивним обструктивним бронхітом та здорових дітей контрольної групи наведений на мал. 4.

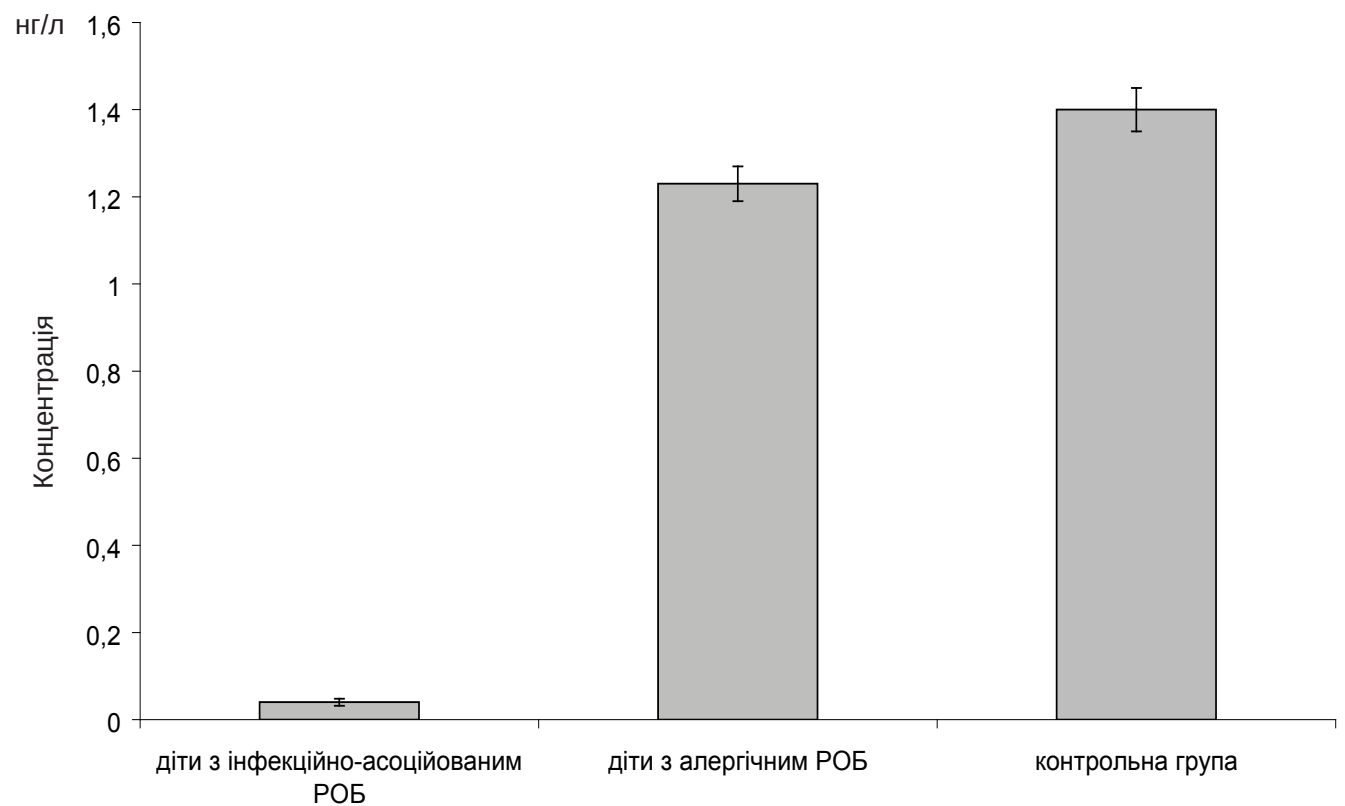

Мал. 4. Середній вміст ІЛ-10 у слині дітей з рецидивним обструктивним бронхітом.

Було встановлено, що в періоді ремісії РОБ у дітей 3 ймовірно алергічним генезом захворювання спостерігається активна продукція ІЛ-10, яка не відрізняється від здорових дітей. Це вказує на достатнє напруження природних механізмів стримування імунної відповіді. Натомість у пацієнтів, в яких прояви захворювання були розцінені як асоційовані з інфекцією, визначалися вкрай низькі рівні ІЛ-10, що вказує на десріцитність супресорної ланки імунітету.

Таким чином, навіть під час клінічної ремісії у дітей з РОБ можна виявити зміни у рівнях ІЛ-4, -6, -8, -10 у слині.

\section{Висновки}

1. Стан ремісії у дітей з РОБ за відсутності клінічних проявів супроводжується імунопатологічними процесами в бронхолегеневій системі. Згідно з напрямками виявлених змін встановлена відповідність між особливостями клінічних проявів, розцінених як ймовірно інорекційно-асоційований та ймовірно алергічний РОБ, та змінами з боку імунної системи. Найбільш доцільним $€$ визначення у дітей з РОБ в періоді ремісії рівнів ІЛ-4 та ІЛ-8, враховуючи, що за цими показниками виявлені найбільші розбіжності не лише між групами хворих, але й із здоровими дітьми.

2. У дітей з алергічним генезом захворювання в періоді ремісії визначається підвищена активність
Т-хелперів 2-го типу. В той же час розвиток інфеекційноасоційованого РОБ супроводжується більш істотними змінами, що полягають у підвищеній активності Т-хелперів 1-го типу та зниженій активності клітин супресорної ланки імунітету, що веде до неконтрольованого запалення в бронхолегеневій системі.

3. Враховуючи, що в дітей з РОБ навіть в періоді ремісії в слині спостерігаються запальні зміни, необхідне удосконалення існуючих схем лікування цих пацієнтів.

\section{Література}

1. Банадига Н.В. Рецидивний бронхіт у дітей / Н.В. Банадига // Новости медицины и фрармации. - 2011. - № 13-14 (333-334) http:// www.mif-ua.com/archive/article/13410

2. Гирина А. Бронхиты у детей: диагностика, лечение, профрилактика / А. Гирина, Н. Короид, А. Заплатников // Врач. - 2014. - N 1. - С. 74-78.

3. Рецидивний обструктивний бронхіт у дітей: попередити чи лікувати? / [Г.С. Сенаторова, О.Л. Логвінова, Н.Р. Бужинська та ін.] // Здоровье ребенка. - 2007. - № 3(6) http://www.mif-ua.com/ archive/article/370

4. Охотникова Е.Н. Рекуррентные инсрекции респираторного тракта у детей и их иммунопросилактика в свете современныхпредставлений об иммуномодулирующей активности иммунотропных препаратов / Е.Н. Охотникова, С.Н. Руденко, Е.Н. Коломиец // Современная педиатрия. - 2013. - № 1(49). - С. 42-50.

5. Симбирцев А.С. Цитокины: классисикация и биологические фрункции / А.С. Симбирцев // Цитокины и воспаление. - 2004. - Т. 3, № 2. - C. 16-23. 
6. The IL-4 receptor: signaling mechanisms and biologic functions / K. Nelms, A.D. Keegan, J. Zamorano et al. // Annu. Rev. Immunol. 1999. - N 17. - Р. 701-738.

7. Медведева М.В. Характеристика цитокинового статуса крови, слёзной жидкости и слюны здоровых лиц, проживающих в регионах с различным уровнем напряжённости геомагнитного поля / М.В. Медведева, П.В. Калуцкий // Курский науч.-практ. вестник «Человек и его здоровье». - 2013. - № 4. - С. 21-25.

8. Слободян Е.И. Содержание интерлейкинов сыворотки крови у детей, больных хроническим пиелонефритом: связь с длительностью заболевания, частотой и активностью обострений / Е.И. Слободян // Таврический мед.-биол. вестник. - 2013. - Т. 16 № 3, Ч. 3 (63). - С. 130-134.

9. Кобец А.А. Динамика цитокинов ИЛ-2, иЛ-4 и индексов крови у детей с атопическим дерматитом с учётом уровня IgE в сыворотке крови / А.А. Кобец // Таврический мед.-биол. вестник. - 2014. - Т. 17, № 2 (66). - С. 65-67.

10. Система про- и противовоспалительных цитокинов при хронических гастродуоденитах у детей / [Э.В. Дудникова, М.А. Шестопалова, О.В. Трофименко и др.] // Современные проблемы науки и образования. - 2012. - № 1.; URL: http://www.science-education. ru/ru/article/view?id=5468 (дата обращения: 23.01.2016).

11. Асмалова А.М. Состояние системного и местного иммунитета у часто болеющих детей с патологией лОР-органов: Автореф. дис... канд. мед. наук / А.М. Асмалова. - Оренбург, 2007. - 28 с.

12. Теплова С.Н. Секреторный иммунитет / С.Н. Теплова, Д.А. Алексеев. - Челябинск, 2002. - С. 143-155.

13. Сравнительная оценка формирования местного иммунного ответа при разных способах аппликации холерного токсина / [Г.И. Васильева, Н.Д. Омельченко, В.Н. Козловский и др.] // Современные проблемы науки и образования. - 2004. № 1. - C. 41-42; URL: http://www.science-education.ru/ru/article/ view?id=2092

\section{DOES CLINICAL REMISSION OF RECURRENT OBSTRUCTIVE BRONCHITIS ABSENCE OF IMMUNOLOGICAL CHANGES IN THE RESPIRATORY TRACT IN CHILDREN?}

\author{
O.O. Yukhymenko
}

SUMMARY. It was performed research of interleukin $4,6,8,10$ in the saliva of patients with recurrent obstructive bronchitis (Rob) during the remission and healthy children. Established that in the absence of clinical manifestations in children continues Rob immunopathological processes. It is shown that with a history, clinical symptoms and results of determination of interleukins 4, 6, 8, 10 in saliva within the group of children with Rob can distinguish two subgroups: patients with infection-associated infectious and allergic genesis Rob disease. Children with allergic genesis of the disease characteristic is burdened allergological history in the family, atopic dermatitis during the first year of life, development of exacerbation after contact with animals or preferably during the flowering plants, the absence of severe temperature reaction during bronchial obstruction syndrome in combination with a significantly increased content of interleukin 4 in saliva. Patients infectious infection-associated Rob typical absence of allergic disease in parents and other family members, seasonality of exacerbations from November to April, the development of exacerbations of bronchial obstruction syndrome in combination with febrile fever and catarrhal symptoms and increased contents in saliva levels of interleukin 6, 8 and decrease contents of interleukin 10. These features can be taken into account in assessing the prognosis of the disease and identifying approaches to differentiated treatment.

Key words: children, respiratory infections, obstructive bronchitis.

Отримано 3.02.2016 p. 